\title{
Onherhaalbaar, onontdoenbaar: Die doop as simbool van eenheid in die kerk
}

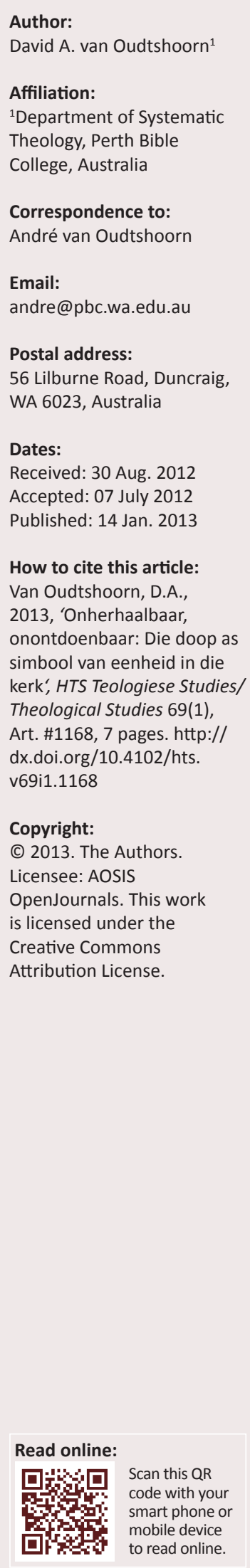

Irrevocably singular: Baptism as a symbol of unity in the church. In this article I conduct a phenomenological analysis of the concept 'one baptism' in Ephesians 4:4-6. Such an analysis seeks to reveal the essence of a particular concept by bracketing out the theological and ideological presuppositions usually associated with it. The essential concept is then expanded by linking it to the terms most closely surrounding it in the text. A critical theological reflection on the expanded concept shows that 'one baptism' refers to an event by which believers are inducted, once and for all, into the church as the one body of the one Lord, Jesus Christ. The church exists through the presence of the one Spirit who binds believers in an unbreakable bond of love to God and to each other. Because baptism can never be undone or repeated, any liturgical act depicted as a 're-baptism' is, by definition, impossible. This means that churches that baptise the children of believing parents are able to accommodate requests from people who, having been baptised as an infant, in later life wish to celebrate and testify to some significant milestone in their spiritual journey by means of an official church ritual. Such ritualised testimonies, however, refer to the existential lifeworld of believers (their repentance, confession of faith etc.) and are distinct from baptism that refers to the singular eschatological work of Christ and thus cannot be repeated. The church should, however, take pastoral care to ensure that people do not substitute their own spiritual experiences for the reality of salvation that is founded on the singular act of God, for us once and for all in Christ, to which baptism irrevocably refers.

\section{Probleemstelling}

Daar is 'n oormaat van teologiese boeke en artikels oor die doop en die verskillende kerklike doopspraktyke soos kinderdoop, geloofsdoop, bekeringsdoop ensovoorts. Dit is nie die doel van hierdie artikel om enigsins verder in te gaan op die teologiese gronde vir sodanige verskillende beskouings in diekerklike praktyknie. ${ }^{1}$ Inteendeel, die argument in hierdie artikel isjuis dat pogings om verskillende beskouinge op die doop as alternatiewe dope teologies teenoor mekaar op te weeg, reeds ten diepste die wese van die doop misken. Vanuit 'n praktiese teologiese perspektief kan ons sê dat die teologiese behandeling van verskillende doopspraktyke in baie gevalle beteken dat die praktyk die teologiese teorievorming rondom die doop bepaal en oorheers. In die praktyk dwing die behoefte aan 'n rituele erkenning van 'n volwasse eksistensiële geloofsbelewenis die kerk om teologies te besin oor hoe die kerklike praktyk om mense te 'herdoop' geëvalueer moet word vanuit die teologiese grondstelling dat daar net een doop is. Die vraag plaas egter reeds 'n bepaalde beperking op die antwoord: In plaas daarvan om hierdie vraag te probeer beantwoord behoort die teologiese teorie eerder 'n wedervraag aan die praktyk te stel, naamlik: Hoe kan daar enigsins sprake van 'n herdoop wees as daar net een doop is?

Die wedervraag ontbloot hierdeur die vooronderstelling dat die kerklike praktyk die reg het om die teologiese teorie te fokus en te beperk. Terwyl praktyk en teorie, volgens die Praktiese Teologie, steeds in 'n bipolêre spanningsveld teenoor mekaar staan, moet daar 'n bepaalde kritiese voorrang aan die teologiese teorie bo die praktyk gegee word. Dit is omdat daar nooit ' $n$ suiwer praktyk bestaan nie - elke praktyk verteenwoordig 'n onderliggende (baie keer verstolde en onbewuste) teologiese teorie, dit wil sê 'n teologies-teoretiese tradisie. Dit is nodig om eers die praktyk te dekonstrueer en die verskuilde teorie te ontbloot voordat vrae vanuit die praktyk krities op die teologiese teorie kan inwerk.

In hierdie artikel gebruik ek 'n fenomenologiese analise van Efesiërs 4:4-6 om die konsep van 'een doop' te deurdink. 'n Fenomenologiese analise van die teks is gegrond op die ideologiese (werklikheidstransformerende) gerigtheid van Bybelse teologiese tekste. Deur die uitskakeling van bepaalde voorveronderstellings word daar gepoog om tot die essensie van die begrip 'een

1.Baie, goeie bronne is gemaklik beskikbaar om die verskillende beskouinge teenoor mekaar op te weeg. Vir ' $n$ analise van vie doopsbeskouinge wat tans in die brandpunt in die Suid-Afrikaanse konteks is, kyk Venter (2010) en König (1986). Die Bybelse grond vir die kinderdoop word goed verwoord in die N.G. Kerk se Roeping en Identiteit (Verslag Moderanum N.G. Kerk 2007). 
doop' te kom. Die begrip word dan verder uitgebrei deur ander aanverwante begrippe in die teks te betrek om die potensiële betekenisse van die fenomeen verder te belig. ' $n$ Krities-teologiese refleksie van die fenomeen 'een doop' in die konteks van die ander konsepte wat dit omraam lei tot die gevolgtrekking dat die doop die dopeling deel maak van die een kerk van Jesus Christus. Die doop plaas die dopeling binne die kragveld van die Heilige Gees wat die gelowiges bly heenwys na hulle geloofseenheid met Christus en, in hom, met mekaar. Hierdie liefdesband van eenheid tussen Christus en sy kerk en tussen gelowiges onderling is onverbreekbaar en die doop funksioneer as simbool daarvan. Omdat die doop begrond is op die unieke persoon en onherhaalbare daad van Christus is herdoop of oordoop onmoontlik. Dit impliseer dat die praktyk waarvolgens mense hulle geloof of bekering simbolies liturgies deur onderdompeling wil bely geakkommodeer kan word binne kerke wat die doop aan kinders van gelowige ouers bedien aangesien sodanige aksie nie as 'n nuwe doop kwalifiseer nie. Daar moet egter steeds pastorale aandag aan enige sodanige versoek gegee word om te verseker dat die Christologiessoteriologiese grondslag van die doop nie verruil word vir 'n antropologiese grondslag nie.

\section{Metodologiese begronding van fenomenologiese diskoersanalise}

Fenomenologiese analise is gerig op die ontbloting van die subjektiewe verstaan van 'n bepaalde sosiaal-gekonstrueerde werklikheid deur diegene verwikkeld in die praktyk daarvan. Volgens Husserl word sodanige sosiale werklikheid voortdurend geskep en herskep binne die bewussyn van mense. Dit geskied in terme van elke individu se verstaan en definisie van sodanige werklikheid aan die hand van hulle eie, persoonlike konteks en ervaringe (Dreyer 1983:127). Die gevolg is dat fenomenologiese analise meestal gekoppel is aan die alledaagse leefwêreld van individue wat 'invoelend' van binne af verstaan moet word in terme van (1) die betekenis wat sodanige persone aan sekere gebeure heg en (2) die subjektiewe intensies wat agter hulle eie handelinge lê (Pieterse 1993:76).

Die vraag is tot watter mate sodanige intuitiewe Verstehen moontlik is in die verstaan van ' $n$ teks (Moustakas 1994:30)? 'n Teks is immers gestolde spraak (parole parlee), 'n objektiveerbare entiteit, eerder as subjektiewe, lewende en skeppende spraak (parole parlante). Die teks verteenwoordig egter ' $n$ bepaalde ideologie wat deur die teks werk om die lesers te oortuig om die werklikheid op dieselfde manier te beleef. $^{2}$ Sodanige ideologie funksioneer binne 'n bepaalde Weltanschauung wat meestal onderliggend en ongeartikuleerd

2.David Janzen (2004:58) sien ideologie sinoniem tot wêreldbeskouing. Brett (1998:132) beskou ideologie as ‘.. a wider complex of contested symbols, values and practices which shape and legitimate the socio-econonomic interest of and practices wh'. Sy definisie van id the socio-econonomic interest of filosic in hie group'. Sy definisie van ideologie is nou gekoppel aan Marx se filosofie. In hierdie artiky definieer ek kultur as is nydste algemene gedeeld sosiale konstruksievan die werklikheid; wereldbeskou'ng as 'n bepaalde konstruksie binne' ('n Christelike wereldbeskouing versus 'n sekulnere wereld binne ' $n$ gedeelde kultuur); en ideologie as ' $n$ meer beperkte uitdrukking van ' $n$ wêreldbeskouing binne' $n$ kleiner groep wat doelbewus hulle spesifieke interpretasie van die werklikheid aanwend om ander te oortuig om soos hulle te dink. binne die teks funksioneer. ${ }^{3}$ Die wêreldbeskouing is gebonde aan die kultuur waarbinne die teks opereer. Kultuur verteenwoordig gedeelde voorveronderstellings tussen die teks en die veronderstelde lesers oor die interpretasie van die werklikheid wat effektiewe kommunikasie moontlik maak of vergemaklik. ' $n$ Ideologie, hierteenoor, is die unieke manier waarop die kommunikant se wêreldbeskouing uitdrukking vind in spesifieke uitsprake met die oog daarop om die werklikheid op 'n bepaalde manier te (her)-interpreteer en te omvorm en om ander mense te oortuig om dieselfde te doen. ${ }^{5}$ Ideologie, net soos teologie, is dus altyd intensioneel. Die intensie van ' $n$ teks word in hierdie artikel verstaan as die toepassing van 'n ideologie, vanuit 'n sekere wêreldbeskouing en binne 'n gedeelde kultuur, op 'n spesifieke konteks om die lesers se interpretasie van die konteks te herskep met die oog op die uiteindelike omvorming van hulle wêreldbeskouing en moontlik ook uiteindelik van hul dominante kultuur. ${ }^{6}$

Indien die teks funksioneer met ' $n$ ideologiese, of in die geval van die Bybel, 'n teologies- ideologiese intensie, kan dit as gespreksgenoot betrek word om nuwe verstaansmoontlikhede oop te maak. Gadamer is van mening dat die leser van ' $n$ teks se eie voorveronderstellings en belewenisse nie teenoor die verstaan van 'n teks staan nie, maar opgeneem moet word in die proses van verstaan (Gadamer, Weinsheimer \& Marshall 2004:XV). Volgens hom lees ons die teks altyd in die lig van 'n tradisie van historiese interpretasies wat nuwe voorveronderstellings vir die verstaan van die teks skep. Ons kan nie eenvoudig daaroor spring om die wêreld van die oorspronklike lesers te betree nie. Terwyl sodanige versmelting van die ons eie verstaanshorison met verskillende historiese geïnterpreteerde verstaanshorisonne 'n bepaalde verbreding inhou, kan daar gevra word of die teks nie daarmee gestroop word van sy dekonstruktiewe mag om ons voorveronderstellings aan die lig te bring en te bevraagteken nie? Dit is duidelik nie wat Gadamer beoog nie. Sy benadering bly daarop gerig om ons vooroordele te korrigeer of opsy te skuif om te kan hoor 'what the text says to us' (Gadamer et al. 2004:XViii). 'n Fenomenologiese analise moet eers alle vooroordele in hakies plaas om tot die essensie van die fenomeen te kom. Daarna kan die verstaansmoontlikhede wat in die teks opgesluit lê deur reflektiewe interpretasie verbreed word (Moustakas 1994:11). Deur die teks fenomenologies te isoleer en ernstig op te neem, asof dit die enigste uitspraak

3.David K. Naugle (2002) wys op 'n reeks verskillende maniere waarop die begrip wêreldbeskouing binne verskillende vakgebiede funksioneer. Daar is geen eenstemmigheid oor' $n$ finale definisie van die begrip nie.

4.Daar is natuurlik baie definisies van kultuur. Die kulturele antropoloog Cyril Hally (in Edwards s.a.:84) dui aan dat meer as 250 definisies van kultuur binne sy vakgebied alleen opereer.

5. Harry Morton Johnson (1960:587) koppel ideologie aan die gedeelde idees binne ' $n$ bepaalde groep. Hiervolgens het ' $n$ individu ' $n$ idee en ' $n$ groep ' $n$ ideologie.

6.Malina (Int. 36:233-240) onderskei drie onderliggende modelle om die sosiokulturele werklikheid te verstaan. Die eerste is die struktureel-funksionele model. Hiervolgens word die gemeenskap as 'n statiese sisteem verstaan waarbinne al die verskillende elemente saamwerk om die struktuur te help onderhou. Enige wysiging van die bestaande struktuur word as 'n bedreiging weerstaan. Hierteenoo wysiging van die bestaande struktuur word as ' $n$ bedreiging weerstaan. Hierteenoo postuleer Stuart Hall ' $n$ meer dinamiese konflik model waarvolgens kultuur verstaa word as die produk van ' $n$ voortdurende stryd om dominansie tussen kompeterende ideologieë. Binne hierdie konteks kan enige teks as ' $n$ ideologiese instrumen gekoopteer word. Hoe meer relevant en effektief die teks beskou word, hoe mee groei die teks in status. Die derde model is die simboliese model waarvolgens die gemeenskap 'n grondliggende interpretasie van die werklikheid skep en onderho deur simboliese betekenisse te verbind aan gewaardeerde voorwerpe en aksies. 
rondom die doop is en volmag het om beide ons teologie en praktyk rondom die doop te bepaal, ontbloot dit juis ons voorveronderstellings en skep die moontlikheid vir nuwe insigte.

Die fenomenologiese metode wat ek in die artikel volg stel dit ten doel om die teologiese intensie van Efesiërs 4:4-6 bloot te lê. Daar is natuurlik ander uitsprake in die Bybel en die teologie rondom die doop wat ook aanspraak kan maak op sodanige fenomenologiese prioriteit. Die teks met haar ryk opeenstapeling van teologiese konsepte rondom 'eenheid' is egter uitnemend geskik om die verband tussen die doop en 'eenheid' in die kerk te ontleed.

Fenomenologiese analise veronderstel 'n bepaalde skeeftrek van enige sistematies teologiese teorie. Alle subjektiewe voorveronderstellings en sistematies-teologiese beskouinge oor die doop word vir eers tussen hakies geplaas in 'n poging om die intensie van hierdie een betrokke uitspraak oor die doop te verstaan. ${ }^{7}$ Op hierdie manier word daar gepoog om die wesenlike van die doop self, te ontbloot. Die lesers is sodanig op die fenomeen van die doop in die teks gerig dat die intensie van die teks die leser kan omvorm om die werklikheid (kerklike praktyk en teologiese teorie) op 'n nuwe manier in die lig van die teks se ideologie of teologie te beskou. Die eenheid van die doop soos dit opereer binne die konteks van die teks word intensioneel beleef en vervolgens tot grondvorm vir die verstaan van die doop verhef. Die 'verskyn' van die fenomeen aan die subjek gebeur verder deur die opname van aanvullende begrippe om die diepte dimensie van die fenomeen te ontbloot en te intensiveer. Hierdie aanvullende begrippe moet verantwoord word op grond van die sterkte van hulle koppeling aan die fenomeen. In die Efesiërs teks waar die doop funksioneer te midde van 'n opstapeling van begrippe (liggaam, Gees, hoop, Heer, geloof, God), en almal gekoppel aan 'een', is die verband duidelik sterk.

In hierdie artikel fokus ek spesifiek op die begrippe wat rondom die term 'een doop' versamel. Die onmiddellike konteks waarin dit figureer dui aan dat hierdie eenheid nie bloot ' $n$ onaantasbare gegewe is nie, maar dat dit binne die konteks van die roeping van gelowiges om in ooreenstemming met God se roeping te handel, opereer:

Laat julle lewenswandel in ooreenstemming wees met die roeping wat julle van God ontvang het. Wees altyd beskeie, vriendelik en geduldig, en verdra mekaar in liefde. Lê julle daarop toe om die eenheid wat die Gees tussen julle gesmee het, te handhaaf deur in vrede met mekaar te lewe. (Ef 4:1b-3)

Dit is duidelik dat kerklike eenheid, alhoewel teologies in God en sy weldade verankerd is, in die gemeentepraktyk deur individuele gemeentelede uitgeleef moet word. Eenheid in die praktyk is, wellinswaar, 'n resultaat van die teenwoordigheid van die Gees in die gemeente. Die gemeente het egter die roeping om hierdie eenheid te bewaak en dit vereis ' $n$ bepaalde positiewe ingesteldheid van gelowiges teenoor mekaar. Gelowiges moet beskeie, vriendelik en geduldig wees en mekaar verdra in liefde:

In Ephesians ... the way to peace is through the gift and the performance of love. Forbearance and bearing one another

7.Die probleem is dat $n$ gebalanseerde sistematies-teologiese beskouing die intensiteit en reikwydte van bepaalde uitsprake kan neutraliseer. in love are skills for maintaining a community of peaceable difference. (Verwey 2011:140)

In Galasiërs 5 word nederigheid, vriendelikheid en geduld as vrug van die Gees in die lewens van gelowiges getipeer. Dat die begrippe hier as imperatiewe funksioneer, alhoewel steeds in die konteks van die werksaamheid van die Gees in die gemeente, kan verklaar word aan die hand van die gemeente se roeping in vers 1 . Die gemeente is geroep om in eenheid en in vrede met mekaar te lewe. Beskeidenheid, vriendelikheid en geduld, die vrug van die Gees, moet deur gelowiges aangewend word om die eenheid wat die Gees tussen gelowiges skep, te bly handhaaf.

\section{Fenomenologiese analise}

Die fenomenologiese analise wat ek volg tabelleer die fenomeen; die kern begrippe of vooroordele wat doelbewus uitgesluit word; nuwe aanverwante begrippe wat ingesluit word om die fenomeen te versterk; en 'n refleksie wat die interpreteerder se begripsvorming verwoord.

\section{Bespreking van fenomenologiese analise}

1. Die doop funksioneer binne die konteks van 'eenheid' in die kerk.

Dit is ironies dat die doop steeds ' $n$ leerstellige stryd in die kerk en tussen kerke veroorsaak. Die verwysing na 'een doop' binne die konteks van Paulus se argument in die geheel van die Efesiërbrief dui op die doop as 'n unieke aksie wat ons in Christus tot ' $n$ eenheid saambind as deel van die nuwe volk van God.

\section{Ballenger (1997) stel dit korrek:}

Notice that the text does not say that we must in some way create or bring about the one Spirit. Oneness is a given, a truth over which we have no control. There is one body and one Spirit, one hope, one Lord, one faith, one baptism, one God and Father of all, a seven-fold oneness that should leave no doubt as to the significance of the affirmation. (bl. 295)

Die een doop, saam met die aanverwante begrippe in Efesiërs 4:1-6 vorm dus die grondslag van ons inlywing in, deelname aan, en eenheid binne, die nuwe volk van God:

When baptismal unity is realized in one holy, catholic, apostolic church, a genuine Christian witness can be made to the healing and reconciling love of God. Therefore, our one baptism into Christ constitutes a call to the churches to overcome their divisions and visibly manifest their fellowship. (WCC's Faith and Order commission 1982)

Die begrip 'een doop' in Efesiërs is verbind aan die unieke objek van die doop, die een Here, Jesus Christus.

Die doop wys verby sigself na Jesus, die Here, wat die finale verwysingspunt of objek van ons Christelike bestaan is. Sonder Jesus is daar immers geen moontlikheid van 'n Christelike geloof, hoop, doop of kerk nie. Hierdie elemente bestaan slegs in terme van hulle verwysing na, en 
TABEL 1: Identifikasie en analise van fenomene.

\begin{tabular}{ll}
\hline Fenomeen & Uitsluit \\
\hline Doop histories & Essener reinigingsrites \\
$\begin{array}{l}\text { Doop histories } \\
\text { Eskatologiese Messiaanse } \\
\text { voorbereidings-doop }\end{array}$ & - \\
\hline $\begin{array}{l}\text { Een doop } \\
\text { Een doop }\end{array}$ & (- meervoudige praktyke) \\
Een doop & (- eenmalige praktyk) \\
\end{tabular}

Refleksie

Die doop van Johannes kan moontlik verbind word aan die reinigingsrites van die Esseners.

Die Christelike doop het egter nie die karakter van konstante herhaling nie.

Die doop van Johannes as voorbereiding vir die koms van die Messias plaas die klem op bekering en belydenis van sonde. Jesus ondergaan ook hierdie doop. Markus 1:8 wys egter op die verskil tussen Johannes se doop met water en die 'doop met die Heilige Gees' wat Jesus sou bring. Die doop met die Heilige Gees behoort aan die nuwe bedeling van die nuwe verbond (Jes 11:2, Joël 2:28, Hand 2:17).

Sien die doop in terme van teologiese teorie in plaas van die praktyk: die begrip van 'een' 'een' is nie doop nie. 'een' is nie doop nie.

Sien die doop sonder ' $n$ voorkeur oor ' $n$ bepaalde vorm van watter doop 'reg' is.

Sien die doop as doop met die Heilige Gees. Handelinge 10:38.

Dit is nie nodig om eers met water gedoop te word om die doop met die Heilige Gees te ontvang nie.

Die doop met die Heilige Gees elimineer nie die 'een doop' as ' $n$ tweede doop nie.

Een doop (- praktyk simboliek)

Sien die doop sonder simboliese funksie in die praktyk. Die doop funksioneer om die gelowige in te lyf in die kragveld van die Heilige Gees.

\begin{tabular}{|c|c|c|}
\hline Een doop & - & (+ water) \\
\hline $\begin{array}{l}\text { Water as simbool in } \mathrm{Ou} \\
\text { Testament (OT) }\end{array}$ & - & $\begin{array}{l}\text { Chaos, bedreiging, } \\
\text { oordeel, dood }\end{array}$ \\
\hline Water as simbool in OT & - & Redding \\
\hline Water as simbool in OT & - & $\begin{array}{l}\text { Reiniging by } \\
\text { verbonds-vernuwing }\end{array}$ \\
\hline Een doop & - & (+ een liggaam) \\
\hline Een liggaam & (- een doop) & (+ een Gees) \\
\hline Een doop & - & $\begin{array}{l}\text { (+ een liggaam } \\
\text { + een Gees) }\end{array}$ \\
\hline Een doop & & $\begin{array}{l}\text { (een liggaam + een Gees } \\
+ \text { een hoop) }\end{array}$ \\
\hline Een doop & (- een Heer) & - \\
\hline Een doop & - & (+ een Here) \\
\hline
\end{tabular}

Sien die doop in die lig van water wat dit aan ' $n$ ritueel-liturgiese praktyk koppel: die doop begin by water as simbool van skoonmaak/liturgiese reiniging/bekering.

Moontlike koppeling aan Jesus wat die dood ingaan ter wille van ons as die lydende kneg (Mark 1:11; Jes 42:1; 1 Pet, 3:18-22).

Redding as weg deur water (Eks 15:8; Jes 51:9-10). Moontlike konnotasie vir eerste gemeentes.

Rituele reiniging voor verbond (Eks 19:10, 14; Jos 2 4:14, 23). Gekoppel aan die Heilige Gees (Eseg 36:25-27; Ps 33:5-7). Moontlike konnotasie vir eerste gemeentes.

Sien dat die doop nie tot meervoudige liggame van Christus kan lei nie.

Sien dat kerk en Gees mekaar veronderstel binne onverbreekbare eenheid. Kan gelowiges deel word van die liggaam deur die doop met die Heilige Gees sonder die doop met water?

Sien dat doop funksioneer binne die konteks van die teenwoordigheid van die een Gees in die een liggaam (kerk) wat onverbreekbaar is.

Die een liggaam, onder beheer van die een Gees, is positief gerig op die toekoms in die een hoop van redding. Die doop is intrinsiek gekoppel aan die eskatologie.

Sonder koppeling aan die een Here verloor die doop sy verwysingspunt.

Net soos daar net een Redder en Middelaar is, so is daar net een doop.

Die doop verbind aan die eenmalige persoon van Jesus sowel as sy eenmalige daad van sterwe en opstanding. Die term Here verbind aan die naam van Jahweh en koppel met 'een God'.

Die term 'Here' verwys na die historiese Jesus.

\begin{tabular}{lll} 
Een doop -Jesus & $\begin{array}{l}\text { (- doop van Jesus deur } \\
\text { Johannes) }\end{array}$ & - \\
\hline Een doop - Jesus & (- ons doop) & (+ doop van Jesus om te \\
ly, te sterf en op te staan)
\end{tabular}

Jesus se doop is deel van sy unieke plaasvervangende werk waardeur hy as Kneg van God homself met ons sonde vereenselwig. Omdat Hy dit as plaasbekleder doen sluit dit ons uit. Ons doop repliseer nie sy doop nie. Hy doop met die Heilige Gees.

Jesus se doop as teken van bekering om vergifnis van God te ontvang is gekoppel aan sy roeping om as Seun van God in ons plek te sterf (Mark 10:38; Luk 12:50). Ons doop verloor daardeur enige selfstandige bestaansreg.

$\begin{array}{ll}\text { Een doop } & \text { (- doop van Jesus om te ly, } \\ \text { te sterf en op te staan) }\end{array}$

Uniek en plaasbekledend vir ons. Ons doop kan alleen heenwys na daardie doop.

Een doop

$\begin{array}{ll}\text { Een doop } & \text { (+om te ly, te sterf } \\ & \text { (en op te staan) }\end{array}$

Ons het saam met Hom gesterf en opgestaan (Rom 6:1-11)

Ons sal ook vir Christus en die koninkryk van God ly.

Een doop

(+ een geloof)

Die een geloof met die inhoud van dit wat God deur Christus gedoen het om mense deel te maak van die liggaam van Christus en wat leef binne die magsfeer van die Heilige Gees, kan nie vervang, verander of vermenigvuldig word nie.

\begin{tabular}{llll} 
Een doop & - & (+ een God) & $\begin{array}{l}\text { Die gedagte dat Christene meer as een God kan aanbid is absurd. Op dieselfde manier is } \\
\text { meer as een doop onmoontlik. }\end{array}$ \\
$\begin{array}{lll}\text { Een God } & \text { (+ een Heer, } & \text { Dat die teks van een God praat binne ' } n \text { konteks waar sowel die een Gees as die een Here } \\
\text { funksioneer, beteken dat een op 'uniek' dui eerder as bloot ' } n \text { numeriese een. }\end{array}$ \\
\hline
\end{tabular}

verbondenheid aan, Jesus, die een Here. ${ }^{8}$ Hulle word deur God drie-enig in Christus deur die werking van die een Gees gekonstitueer met die doel om 'n volk te skep om deel te hê aan die missio Dei - om die hele wêreld onder die finale heerskappy van die een God te bring.

2. 'Een doop' verwys nie bloot na 'n eenmalige doop-aksie nie, maar na die onvervangbare gerigtheid van die doop op Jesus Christus. Dit impliseer dat daar geen sprake van 'n tweede doop in die kerk kan wees nie.

8.'The next reference to "one" - "one baptism" - complements "one Lord" and "one faith" as a triad. It is in the one baptism that the audience share with all other believers the confession of their one faith in the one Lord' (Heil 2007:73).
Omdat Jesus die unieke en eenduidige verwysingspunt van die doop is, kan daar nie ' $n$ tweede (of ander) doop buite of los van hom bestaan nie. Net soos dit onmoontlik is om in 'n ander Middelaar as Jesus te glo en daardeur deel van die volk van God te word, so is dit onmoontlik om in 'n ander naam as die naam van Jesus gedoop te word. Wie in Jesus glo, bely hom as die Here en word daarom in sy naam gedoop as toetrede tot die volk van God (Tomkins \& Churches 1961:56).

Die 'een doop' verwys dus nie bloot na 'n numeriese 'een' nie, maar eerder na die uniekheid van die doop as gebonde aan die een Here, Jesus Christus, deur die een geloof wat lei tot een hoop en een kerk. Net soos 'een God' nie dui op 
'n numeriese enkele God wat alleen en eensaam in homself bestaan nie, maar op 'n eenheid wat die menigvuldigheid van Vader, Seun en Gees kan akkommodeer, so verwys die 'een doop' na die doop se eenduidige gerigtheid op Jesus wat die dopeling deel maak van die een kerk eerder as bloot na 'n enkele, eenmalige en onherhaalbare doopspraktyk (Martin 1991:49).

3. Wanneer 'een doop' as 'n numeries-eenmalige doopspraktyk beskou word, word alle ander doop-aksies noodwendig as verkeerd beskou - al geskied hulle in die naam van die een Here, Jesus Christus.

Die dogmatiese stryd oor wie se doopspraktyk eintlik 'reg' is, is die resultaat van 'n koppeling van 'een doop' aan die doopspraktyk eerder as aan die doopteorie waarin die 'een doop' die unieke, wesenlike karakter van die doop op Jesus Christus betrek. Waar iemand 'n 'tweede keer' gedoop word, word die eerste doopspraktyk daardeur per definisie as verkeerd en ongeldig verklaar:

Lidmate wat hulle laat herdoop het, meen verniet dat die kerke wat hulle tot grootdoop oortuig het, dit sal aanvaar as hulle nog die betekenis van hulle kleindoop handhaaf. Dit impliseer tog juis dat die kerke wat mense herdoop daarmee sê dat die kleindoop nie reg is nie. Mens kan dit nie anders sien nie, as 'n verwerping van die kinderdoop as geldige doop. En enige poging van die NG Kerk om 'n tweede doop (al noem mens dit ook wat) toe te laat, sal hierdie standpunt eenvoudig bevestig. (Verslag Moderanum N.G. Kerk 2007, Bylae 3)

Kerke wie se doopsaksie so ongeldig verklaar word, verweer hulle deur op hulle beurt die doop van die wederdopers te verwerp as die 'verkeerde' doop. In die Nederduits Gereformeerde Kerk is lidmate wat hulle laat herdoop het, vir baie jare onder die tug geplaas - met die implikasie dat as hulle hul nie bekeer het nie, hulle uiteindelik buite die Koninkryk geplaas moes word:

Die vroeëre tughantering van die kerk rondom mense wat hulle laat herdoop het, waarin dit van sodanige lidmate verwag was om hulle skuld aan dwaling en ongehoorsaamheid eers te bely, voordat hulle weer volwaardig as lidmate in die kerk opgeneem kan word, het groot skade berokken aan toegewyde kinders van die Here. Meestal het hulle werklik gemeen dat hulle maar net aan God gehoorsaam wil wees - veral as dit gepaard gegaan het met die belewing van een of ander krisis in hulle lewens, of as hulle tot 'n nuwe toewyding en geestelike verdieping in hulle lewens geraak het. Dit is vir hulle onmoontlik om die 'sonde' in so 'n beskouing en handeling te bely, as hulle opreg glo dat hulle reg doen - en as hulle met die nuwe erns van hulle geloofslewe wat die herdoop voorafgegaan het, sonder skroom 'n positiewe getuienis wil lewer van dit wat God in hulle lewens gedoen het. (Verslag Moderanum N.G. Kerk 2007, Bylae 3)

Die besluit van die N.G. Kerk se Algemene Sinode in 1998 rondom herdoop is:

... dat die herdoop van lidmate die eenmalige betekenis van die doop geweld aandoen. In beginsel moet dit egter as ' $n$ dwaling binne die Christenskap gesien word en daarom pastoraal gehanteer word. (Verslag Moderanum N.G. Kerk 2007, Bylae 3)

Teologies-teoreties is daar egter nie die moontlikheid van 'n 'verkeerde' doopspraktyk nie - solank as wat die doopspraktyk in die naam van Jesus Christus geskied. Die essensie van die doop, dit wat dit uniek 'een' maak lê immers, soos reeds aangedui, buite die konteks van die doopspraktyk, dit is geborge in Christus self:

Ons glo ook dat die geldigheid van die doop nie afhang van ons aanvaarding daarvan nie. Dit berus in God self. Die grondslag van ons verlossing en die ontvangs van die genade van God oor ons, is alleen in God te vind (dink weer aan die sola gratia). (Pieterse 2011:48)

Dat die doop ten diepste fenomenologies in God drie-enig as die subjek in die doopsgebeure verankerd is, is duidelik uit die manier hoe die outeur in vers 4 met 'n verwysing na die Gees begin om dan via die Christologie in vers 5 met die alwerksame God in vers 6 te eindig. God word in hierdie vers beskryf as 'één God en Vader van almal: Hy wat oor almal is, deur almal werk en in almal woon'. God, as Vader, bind die gelowiges (almal) saam tot 'n eenheid. Sy heerskappy as die een oor almal, vereis eenheid tussen gelowiges; sy betrokkenheid deur almal skakel gelowiges in in die uitwerking van sy wil om eenheid binne die kerk te handhaaf; en sy teenwoordigheid in almal dui op sy immanente betrokkenheid deur die Gees om die voorwaarde vir eenheid in die kerk, naamlik die vrug van die Gees - beskeidenheid, vriendelikheid, geduld (Gal 5), in gelowiges te laat realiseer. Hoehner (2002) kom tot die volgende slotsom:

The Trinity is an integral part of this treatise on unity ... All seven components are united in the trinity. Some scholars such as Kirby, think that baptism is central and some like Hanson think that faith is central, but in reality the triune God is the center and model for unity. (bl. 520)

Die doop opereer dus binne die konteks van die werk van God drie-enig, en die werk van hierdie God is ten diepste gekoppel aan die saamsnoering van gelowiges onder sy liefdevolle vaderskap.

Die Algemene Sinode se stelling dat 'n 'verkeerde' '(her) doop kan geskied "binne die Christenskap"', impliseer die aanvaarding dat die doopspraktyk nie die gelowige se inlywing, deelname aan, en status binne die kerk as liggaam van Christus - tog die enigste vorm van 'Christenskap' - kan bedreig nie. Die onderliggende getuienis, dat die unieke essensie van die doop buite die doopspraktyk, by God drieenig self lê, word ongelukkig egter nie verder ontwikkel nie.

4. Omdat die doop verwys na die eenmalige werk van Christus om die kerk as liggaam van Christus tot stand te bring, dra die doop altyd die karakter van geloofsfeesviering en geloofsgetuienis. Die doop is egter nie 'n aktiewe element in ons redding of inlywing tot die liggaam van Christus of volk van God nie.

Die doop dra nie by tot die inlywing van die gelowige deur Christus in die liggaam van Christus nie. Dit reflekteer slegs hierdie inlywing in die konteks van gelowige feesviering en geloofsgetuienis dat Christus alleen ons redding bewerk het. In die kinderdoop vier gelowige ouers God se verbond met die gesin wat verby hulle individuele geloof uitreik om hul kinders in te sluit. Die ouers doen dit in die geloofsverwagting 
dat hulle kinders self in geloof sal antwoord op dit wat Christus vir gebroke sondaars gedoen het om hulle deel van sy volk te maak. In die 'geloofsdoop' of 'bekeringsdoop' vier die gemeente die dopeling se getuienis dat hy of sy glo dat Jesus reeds alles klaar gedoen het om sondaars te red en in te lyf in die familie of volk van God. Indien die doop nie steeds in gelowige afhanklikheid heenwys na die eenmalige daad van God in Christus om sondaars te red nie, kwalifiseer dit nie as 'n Christelike doop nie.

5. Die doop plaas die dopeling binne die kragveld van die Heilige Gees in die kerk sonder om daardeur die kerk in die plek van Christus te stel as grond van die dopeling se redding.

Die doop is meer as bloot ' $n$ simbool wat heenwys na die verlede. Die doop geskied binne die konteks van die kerk. Die kerk se synsgrond is die teenwoordigheid van die Heilige Gees as voorteken van die vervulling van God se belofte dat die gelowiges deel het aan die nuwe verbond of nuwe volk van God. Die kerk simboliseer nie slegs gelowiges se nuwe status as deel van die eskatologiese volk van God nie, maar is reeds die proleptiese vervulling daarvan in die hier en nou. Deur die doop as inlywing tot die kerk beleef die dopeling reeds sy of haar deelname aan die liggaam van Christus of volk van God. Soos reeds aangedui: die doop maak die dopeling nie deel van die volk van God nie - dit geskied alleen in en deur Christus; die doop maak die dopeling egter deel van die kerk wat opereer en bestaan binne die kragveld van die Heilige Gees. Die Heilige Gees is veranderend besig in die kerk om gelowiges te omskep tot beelddraers van Christus. Die kerk ervaar dit egter slegs deur haar geloof in Jesus Christus. Ons kan sê dat die eskatologiese teenwoordigheid van Jesus binne die kerk tot uitdrukking kom deur die teenwoordigheid van die Heilige Gees. Die kerk op haar beurt gee slegs uitdrukking aan hierdie teenwoordigheid deur haar geloof in, en belydenis van, Jesus Christus. Diegene wat die doop as merkteken van hul lidmaatskap aan die kerk ontvang, moet steeds deur hul persoonlike geloof in Jesus Christus hul deelname aan die eskatologiese kragveld van die Heilige Gees hul eie maak. Kittel se stelling, 'baptism implies participation in the life and death and resurrection of Christ, ...' moet uitgebrei word met die woorde 'by faith'. Wanneer dit gebeur is wat hy vervolgens sê, korrek:

The break from sin is thereby accomplished and attachment to the life of the new creation effected, yet is such a way that in this aeon the translation into empirical reality of what God has posited remains, or rather becomes, a task for the baptized. (Kittel \& Friedrich 1964:544)

6. Die 'een doop' beteken dat dit waarvan die doop getuig - volkome geloofsafhanklikheid aan Christus, op verskillende simboliese maniere gevier kan word - ook deur die herhaling van die uiterlike simboliese doopsaksie. Dit impliseer nie ' $n$ ander doop, of tweede doop wat die eerste doop vervang nie. Die Christologiese karakter van die doop beteken dat ' $n$ tweede doop nie kan bestaan nie. Die doop wat altyd bly heenwys na ons inlywing by die kerk as liggaam van Christus op grond van Christus se verdienste alleen, kan slegs, in enige herhaling daarvan, opnuut bevestig word.

Die wese van die doop lê in die onherhaalbaarheid daarvan:

As an eschatological act, baptism is necessarily administered once for all and is unrepeatable. It is an act of decisive and final significance because the final and decisive redemptive act of God in Christ has been made effective to the Christian and he is brought within its scope. (Tomkins \& Churches 1961:65)

Die probleem van gelowiges wat hulle doop wil herhaal, bly steeds by die kerk. Indien die moontlikheid van 'n tweede, plaasvervangende doop nie teologies-teoreties bestaan nie, impliseer dit dat die doop in wese alleenlik herbevestig kan word deur soortgelyke of aanverwante simbole te gebruik. Sodanige seremonies skep die pastorale moontlikheid vir die eksistensiële belewenis van gelowiges se geloofsvertroue in Christus asook die moontlikheid van 'n uiterlike getuienis van hulle geloof of wegdraai van sonde. Om dit duidelik te maak dat sodanige simboliese aksies nie die doop kan vervang nie, moet die kerk moontlik die konsep van 'herdoop' of 'oordoop' vermy en eerder praat van 'belydenisonderdompeling' of 'bekeringsonderdompeling'. Belydenis en bekering vorm immers deel van die normale Christelike lewe. By belydenisonderdompeling kan die dopeling byvoorbeeld getuig: 'Hiermee getuig ek ... dat ek alleenlik deur genade gered is op grond van dit wat Christus vir my aan die kruis en deur sy opstanding gedoen het', terwyl die liturg kan sê: 'Hiermee bevestig ons jou doop as kind wat jou toetrede tot die heil in Christus en sy gemeente verleen het, en jou geloofsverbintenis aan (geloofsbelydenis van) God die Vader, die Seun en die Heilige Gees.'

7. 'n Versoek om die doop te herhaal moet eers teologiespastoraal hanteer word om te verseker dat die doop steeds Christologies en kerklik-korporatief eerder as bloot individueel-antropologies verstaan word.

Die doop se verbintenis aan die eenmalige werk van Christus, beteken dat die gemeente pastoraal aandag moet gee wanneer iemand 'weer' gedoop wil word, om te verseker dat die gelowige nie die doop verkeerd verstaan as iets wat bydra tot sy of haar redding nie. Wanneer die doop bloot aan die geloofsbelewenis van die individu gekoppel word, los van die geloof se inhoudelike verwysing na die eenmalige werk van Christus, word die vaste grond van die heilswerk in Christus verruil vir 'n feilbare antropologiese fondasie. Pastorale sorg reik egter uit na die hele mens, en die behoefte by sekere lidmate vir ' $n$ openbare simboliese belydenis gekoppel aan die idee van doop of onderdompeling moet nie lig van gemaak word nie.

\section{Samevattend}

In hierdie artikel is ' $n$ fenomenologiese analise van die doop volgens Efesiërs 4:6-8 gedoen. Die intensie van die uitspraak 'een doop' is ernstig opgeneem en aangewend om praktyk-en 9.Belydenis of bekeringsdoop kan ook aangewend word indien dit duidelik genoeg onderskei word van die heilsdoop in Christus. 
teologiese voorveronderstellings oor die doop tussen hakies te plaas. Die konsep 'een doop' is sodoende geïsoleer van ander teologiese uitsprake wat die intensie van die uitspraak kan verminder. Deur 'een doop' te verstaan in die lig van die ander begrippe wat dit omraam is die reikwydte van die begrip vermeerder. Die insigte wat hieruit voortgekom het is aangewend om verder oor die konsep van die doop te reflekteer. Die gedagte dat 'een doop' die moontlikheid van 'n tweede doop uitskakel is toegepas op die praktyk van 'her'-doop. Die doop as geloofsfeesviering wys heen na die unieke onherhaalbare daad van Christus. Die uiterlike herhaling daarvan kan egter nie die eerste doop tot niet maak nie. Deur die moontlikheid van 'n tweede doop te ontken, word die evaluasie van 'n bepaalde vorm van die doop as 'reg' of 'verkeerd' afgewys. Die doopsritueel is inlywing in die kerk as kragveld van die Heilige Gees, maar dit is en bly geloof in Jesus wat die kragveld aktualiseer in die kerk en in die gelowige. Die doop se begronding op die unieke persoon en heilsdaad van Christus beteken dat dit 'n onverbreekbare band van eenheid tussen gelowiges vorm. Die doop staan as die teken dat gelowiges onverbreekbaar aan Christus en daarom aan mekaar behoort. Die doop funksioneer dus as die teken en simbool van onverbreekbare eenheid in die kerk.

\section{Erkenning \\ Mededingende belange}

Die outeur verklaar dat hy geen finansiële of persoonlike verbintenis het met enige party wat hom nadelig kon beïnvloed in die skryf van hierdie artikel nie.

\section{Literatuurverwysings}

Ballenger, I.E., 1997, 'Ephesians 4:1-16', Interpretation 51(3), 292-295. http://dx.doi. org/10.1177/002096439605100309

Brett, B., 1998, 'Biblical Studies and Theology: Negotiationg the Intersections', Biblical Interpretation 6(2), 131-141. http://dx.doi.org/10.1163/156851598X00363

Dreyer, P.S., 1983, Objek en metode in die geesteswetenskappe, Universiteit van Pretoria, Pretoria.

Edwards, D., s.a., 'Christ and Culture - Some Preliminary Reflections', Colloquium 28(2), 81-94

Gadamer, H.G., Weinsheimer, J. \& Marshall, D.G., 2004, Truth and method, Continuum International Publishing Group, New York.

Heil, J.P., 2007, Ephesians: empowerment to walk in love for the unity of all in Christ, Society of Biblical Lit., Atlanta, GA.

Hoehner, H.W., 2002, Ephesians, an exegetical commentary, Baker, Grand Rapids, MI.

Janzen, D., 2004, The social meanings of sacrifice in the Hebrew Bible: A study of four writings, Walter de Gruyter, Berlin.

Johnson, H.M., 1960, Sociology: A systematic introduction, Allied Publishers, New Delhi.

König, A., 1986, Die doop as kinderdoop en grootdoop, NGKB, Pretoria.

Kittel, G. \& Friedrich, G., 1974, Theological dictionary of the New Testament, Eerdmans, Grand Rapids, MI.

Martin, R.P., 1991, Ephesians, Colossians, and Philemon, Westminster John Knox Press, Louisville, KY.

Moustakas, C.E., 1994, Phenomenological research methods, SAGE, Thousand Oaks, CA. Naugle, D.K., 2002, Worldview: The history of a concept, Eerdmans, Grand Rapids, MI.

Pieterse, H.J., 1993, Praktiese teologie as kommunikatiewe handelingswetenskap, RGN uitgewers, Pretoria.

Pieterse, H.J., 2011, 'Die Reformatoriese kerklike landskap', in C. Vos \& D. Human (reds.), Vaste Rots op wie ek bou, pp. 37-52, Lux Verbi, Kaapstad.

Tomkins, O. \& Churches, W.C., 1961, One Lord, one baptism: World Council of Churches, Commission on Faith and Order report on the divine Trinity and the unity of baptism, by the Theological Commission on Christ and the Curch, World Council of Churches, Geneva.

Venter, P., 2010, Nuwe Testamentiese perspektiewe op die doop as herhaalbare verbondsteken: 'n Eksegeties-dogmatiese ondersoek, Universiteit van Pretoria, Pretoria.

Verhey, A., 2011, Ephesians, John Knox, Westminster.

Verslag Moderanum N.G. Kerk, 2007, Roeping en identiteit, Nederduits Gereformeerde Kerk, besigtig 14 November 2010, by http://www.ngkerk.org.za/documents/Agenda

WCC's Faith and Order commission, 1982, Baptism, Eucharist and Ministry, World Council of Churches, Geneva. 